BLS 34, No 1 2008. DOI: http://dx.doi.org/10.3765/bls.v34i1.3584

(published by the Berkeley Linguistics Society and the Linguistic Society of America)

\title{
Prosody, Accessibility, and Sentential Negation in Brazilian Portuguese
}

\author{
MEGHAN E. ARMSTRONG \& SCOTT A. SCHWENTER \\ The Ohio State University
}

\section{Introduction}

Information structure refers to a speaker's choice of linguistic form as it relates to the same speaker's evaluation of her hearer's mental state/attitude. (Lambrecht 1994). In conversation, speakers make hypotheses about the beliefs of their interlocutors, and choose linguistic forms based on these hypotheses. Lambrecht points out that while hypotheses formed by speakers about their hearers' mental states are psychological phenomena, information structure is not in fact psychological, but purely linguistic. He categorizes information structure as a grammatical component, and more specifically as part of sentence grammar, and as potentially manifested in prosodic, syntactic and lexical phenomena. This paper investigates information structure as it relates to canonical and non-canonical syntactic constructions of negation in Brazilian Portuguese (henceforth BP), and the prosodic correlates associated with these constructions.

There is a wealth of evidence, at least for West Germanic languages, supporting the argument that prosody and information structure are closely related. Studies have presented evidence that new information is marked with pitch accent where discourse-old or given information may not carry pitch accent at all (Baumann \& Grice 2006). However, more careful study reveals that this simple dichotomy is insufficient to account for the relationship between prosody and information structure; the relationship seems to be much more gradient. Terken and Hirschberg (1994) found that, for English, deaccenting is dependent not only on givenness, but also on grammatical function and persistence of surface position. They concluded that speakers use deaccenting when conveying meaning deemed highly accessible in the discourse. These authors propose that deaccentuation is used anaphorically, pointing back to some antecedent that is accessible for the hearer. Baumann and Grice (2006) further develop this research program focusing explicitly on the relationship between discourse accessibility and pitch accent. These authors reinforce the variability in terms of givenness as well as accessibility, such that information can be given or accessible to varying 
degrees. These authors' results showed a high correlation between 'type of pitch accent' and 'type of accessibility', supporting Lambrecht's (1994) view that a direct phonological correlate of accessible information does not exist. In addition, Baumann \& Grice claim that prosodic marking of accessible information is by no means arbitrary. Following Chafe (1994), they argue for an intermediate category between new and given information: active (given), semi-active (accessible) and inactive (new). Baumann \& Grice propose a scale relating pitch accent type and accessibility type as in (1):

Pitch accent type by accessibility type.

$\begin{array}{ccr}\text { Active } & \text { Semi-Active } & \text { Inactive } \\ - \text { No accent }^{-} & \mathrm{H}+\mathrm{L}^{*} & \mathrm{H}\end{array}$

The scale predicts that the more predictable the information, the less likely pitch accenting will be for English.

\section{Deaccenting of highly accessible information}

The use of deaccenting in languages outside of West Germanic is not well researched. In a recent study, Cruttenden (2006) presented evidence for deaccenting as a cognitive universal in a study of twelve languages. Using repetition as an indicator of givenness, in order to assess how givenness and deaccenting correlate crosslinguistically, Cruttenden argues for the existence of obligatory deaccenting in English. In addition, for BP, he cites the following example, taken from Crystal (1975:40):

\section{[Este livro custa cinco DOLARES] [e este aqui três DOLARES].}

'This book costs five dollars and this one here costs three dollars.'

Though Cruttenden did not include BP in his cross-linguistic survey, he notes that (2) follows a tendency in BP to place prominence on the last item in a tone unit even when repeated in a coordinate construction. He concludes that deaccenting is not in fact a cognitive universal, or at least not a straightforward one. His results showed that Arabic and Romance languages actually disfavor deaccenting of repeated information while Greek \& German favor deaccenting, like English.

Baltazani (2006) explored the relationship between prosody and information structure for negation in Greek, a language that uses both prosody and word order to mark information status. A $\mathrm{L}+\mathrm{H}^{*}$ pitch accent as well as longer duration for both topic and focus are found for any utterance in Greek. Consequently, information appearing after the focus is typically deaccented (Baltazani 2006). Baltazani refers to this deaccented information as the "tail" (cf. Vallduví 1990). Relevant to our study, Baltazani discusses topic and tail as they relate to discourse accessibility, and claims that the main difference between the two is that while 


\section{Prosody, Accessibility and Sentential Negation}

both contain given information, tails must contain explicitly given information. There are two types of melodies for negation in Greek, as outlined in (3):

Two types of melodies for negation in Greek (new vs. given)

\begin{tabular}{|l|l|}
\hline Negation & $\begin{array}{l}\mathrm{L} *+\mathrm{H} \text { nuclear pitch accent with all of } \\
\text { the following material deaccented. H } \\
\text { boundary tone. Does not matter whether } \\
\text { constituents following negative particle } \\
\text { are new or given. Negation is the new } \\
\text { information. }\end{array}$ \\
\hline Given & $\begin{array}{l}\text { Negation does not receive main } \\
\text { sentence stress. Sentence does not have } \\
\text { a feel of a negative sentence. }\end{array}$ \\
\hline
\end{tabular}

Therefore, in Greek there is a $\mathrm{L}+\mathrm{H}^{*}$ pitch accent on the negative particle followed by deaccenting (regardless of the information status of the material after the negative particle), but when the negation is not new to the discourse the negative particle does not receive main sentence stress. The rule of deaccenting all information after the negative particle, then, becomes problematic since tails must occur post-focally and can only contain given information. To resolve this issue, Baltazani claims that elided material encodes discourse-given information. Discourse-new material, by contrast, is deaccented. Chafe proposed a possible cross-linguistic universal that "given information is conveyed in a weaker and more attenuated manner than new" (1976:31). Applying this to Greek, it seems there are marked and unmarked cases for tails in Greek such that for the unmarked case the tail contains information that is necessarily given and deaccented. However, because all information after an accented negative particle must be deaccented but not necessarily given, deaccenting is no longer sufficient to encode information status. This is an extreme case of attenuation such that given information is elided and new information is deaccented. Thus, in out-ofthe-blue negative utterances in Greek, the scale for encoding tail information shifts from a pitch vs. non-pitch dichotomy to a non-elided/deaccented vs. elided dichotomy. Given information, conveyed via ellipsis, is still weaker than the deaccented information that is segmentally present.

\section{Deaccenting in $\mathrm{BP}$}

As noted, Cruttenden did not include BP in his cross-linguistic study of deaccenting as a cognitive universal across languages. Indeed, it has not been explicitly claimed that deaccenting in BP is an acoustic signal of givenness. In de Morães' (1998) discussion of BP intonation, he provides a sentence which exemplifies both negation, and what presumably is deaccenting in BP: 
Meghan E. Armstrong and Scott A. Schwenter

Você só foi lá em casa porque estava chovendo.

'You only went to my house because it was raining.'

[Eu NÃO fui a sua CAsa] [porque estava choVENdo].

'I didn't go to your house because it was raining.'

In de Morães' interpretation of the intonation contours of this utterance, the negative particle is new information and receives pitch accent, and the rest of the sentence is redundant. He implies that "the rest" of the material in (4) is given, and therefore deaccented, but does not make this claim explicitly. Following de Morães' explanation, however, it appears there exists a prosodic distinction in BP signaling a contrast between new and given information.

\section{Negation in (Spoken) BP}

Like pitch accent, non-canonical syntactic constructions are also reliant on information status. Non-canonical constructions are predictable in that they depend heavily on both discourse status and hearer status (Ward \& Birner 2006). Relevant for us, these constructions are also sensitive to whether a discourse entity is evoked or can be inferred from something else that was already evoked. With these facts in mind, it seems that non-canonical structures would provide a reliable testing ground for prosodic correlates that are also sensitive to information status. Assuming that deaccenting signals highly accessible information, a likely place to find such a contour would be a non-canonical structure that depends on highly accessible information. Further, the canonical version of such a structure would then be helpful since it would not rely so heavily on information status. The present study uses non-canonical and canonical structures of sentence negation in spoken BP to confirm whether speakers use deaccenting to encode given information through prosody.

There are three morphosyntactic constructions, termed NEG1, NEG2, and NEG3, to express sentential negation in spoken BP (Schwenter 2005). NEG1 displays canonical preverbal negation (5a); NEG2 repeats the preverbal negative in utterance-final position (5b); and NEG3 employs the negative only postverbally (5c). Although all three forms express the same propositional content, they are pragmatically distinct. ${ }^{1}$

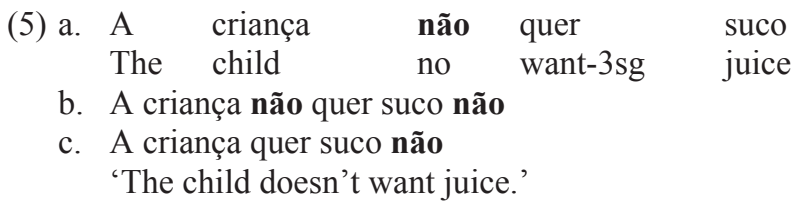

NEG1)

(NEG2)

(NEG3)

\footnotetext{
${ }^{1}$ Usage for the three forms varies as well, as shown in the frequency distribution across forms found by Alkmim (2001) in her study of the Mineiro dialect: NEG1 ( 75\%) > NEG2 ( 20\%) > NEG3 ( 5\%).
} 
Schwenter characterizes the forms' pragmatic division of labor as in (6):

(6) BP negatives by information status of the negated proposition (Schwenter 2005)

\begin{tabular}{l|ccc}
\hline Form & Discourse-New & Inferrable & Explicitly Activated \\
\hline NEG1 & OK & OK & OK \\
NEG2 & $\#$ & OK & OK \\
NEG3 & $\#$ & $\#$ & OK \\
\hline
\end{tabular}

Here there is a scalar relationship between these forms in terms of their dependence on discourse context: NEG1 is not dependent on discourse context, NEG2 is more dependent and NEG3 is fully dependent, as depicted in (7).

(7) Scale of discourse dependence for BP negatives

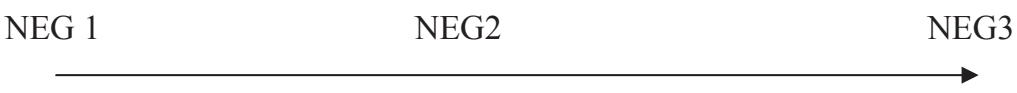
Not dependent
More dependent
Completely dependent

Assuming that deaccenting encodes high accessibility of a discourse entity, we present in (8) our hypotheses for deaccenting and its possible interaction with sentential negation in declaratives in BP.

(8) Hypotheses for relationship between deaccenting and BP sentence negation

\begin{tabular}{|l|l|}
\hline Hypothesis 1 & NEG1 may or may not show deaccenting, depending on context. \\
\hline Hypothesis 2 & $\begin{array}{l}\text { For non-canonical structures in BP that rely on information that } \\
\text { has been explicitly activated, there should be evidence for } \\
\text { deaccenting. Drawing on prior claims that deaccenting is more } \\
\text { common for given information but not obligatory, we } \\
\text { hypothesize that this will hold true for BP as well }\end{array}$ \\
\hline Hypothesis 3 & $\begin{array}{l}\text { Assuming that prosodic correlates are found for the non- } \\
\text { canonical structures, NEG2 should show a prosodic contour } \\
\text { more similar to NEG3 when elicited by explicitly activated } \\
\text { information, but may show a distinct contour when negated } \\
\text { information is inferrable. }\end{array}$ \\
\hline
\end{tabular}

\section{BP Intonation}

The autosegmental framework assumes for BP that the main property of neutral declaratives is a $\mathrm{H}+\mathrm{L}^{*}$ bitonal pitch accent associated with the head of phonological phrase $(\varphi)$ of the intonational phrase (I). These neutral declaratives 
have a low (L\%) boundary tone at the right of I when the last posttonic syllable of I is realized (Tenani 2002; Fernandes 2007). In the same framework, the ToBI system (Beckman and Hirschberg 1994) was initially developed for prosodic transcription of English. The ToBIPI system for BP, which is still under development (Lucente 2007) assumes the following tones for BP: $\mathrm{L}^{*}, \mathrm{H}^{*}, \mathrm{~L}^{*}+\mathrm{H}$, $\mathrm{H}^{*}+\mathrm{L}, \mathrm{H}+\mathrm{H}^{*}$ with $\mathrm{L} \%$ and $\mathrm{H} \%$ boundary tones.

As regards the occurrence vs. non-occurrence of pitch accent, Fernandes (2007) provides evidence for the distribution of pitch accents with respect to focused elements. She makes the following generalizations (our translation):

(i) Focused elements may have the same pitch accent that they receive in a neutral context $\left(\mathrm{H}^{*}+\mathrm{L}\right.$ versus $\left.\mathrm{L}^{*}+\mathrm{H}\right)$ or they may have the same tonal combination that they would receive in a neutral context $\left(\mathrm{L}^{*}+\mathrm{H}\right)$.

(ii) Sentences with a focused subject show, as a critical characteristic that distinguishes them from neutral sentences, the absence of tonal accents associated with intermediate phonological words (between the head of $\varphi$ which contains the focused subject and the syllable head of the last $\varphi$ of I.

(iii) Predominance of a focal accent associated with the right boundary of $\varphi$ which contains the focused subject.

Fernandes' second generalization suggests that material not in focus may not receive a tonal accent. The pitch track in (9) (Fernandes 2007) looks very much like F0 contours that signal deaccenting.

(9) Prosodic focus in BP

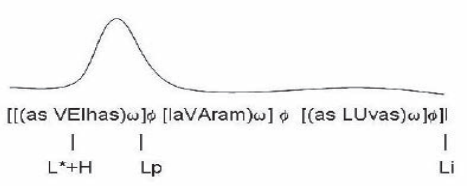

As velhas lavaram as luvas 'The old women washed the gloves'

(9) was produced in a context where what was presupposed was that someone washed the gloves. The new information carries $\mathrm{L}^{*}+\mathrm{H}$ bitonal pitch accent but the given information carries no pitch accent.

\section{Data}

Our data for BP sentential negatives were collected from 5 native speakers of BP from the following cities: Recife (1), São Paulo (2), Rio de Janeiro (1), and Franca (1). Speakers were presented with context as well as scripted utterances that were responses to questions or reactions to a given context. Data from the speaker from Recife were not used because it presented intonational patterns that were found to be different from the other dialects surveyed. At this point it is not clear whether these are dialectal differences for the Recife variety of BP or 


\section{Prosody, Accessibility and Sentential Negation}

whether the differences were idiolectal. We also reference decontextualized data from Armstrong et al. (2008), which we turn to now.

The data presented in this section were chosen because they are representative of typical patterns found in felicitous contexts for the various forms of negation in BP. These examples as they serve as adequate tests for Hypotheses 1,2 and 3 (henceforth H1, H2 and H3) laid out in (8) above. In this section we detail each hypothesis, presenting data to support each one.

First, as regards H1, lab speech from Armstrong et al. (2008) showed a typical $\mathrm{L}+\mathrm{H}^{*}$ initial rise on the negative particle for NEG1 (canonical negation):

(10) Typical NEG1 with initial $\mathrm{L}+\mathrm{H}^{*}$ rise and accented propositional content (Decontextualized utterance).

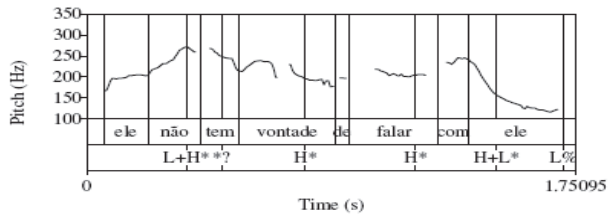

Ele não tem vontade de falar com ele.

'He doesn't feel like talking to him.'

This canonical structure corroborates well-known claims in the literature describing a drop in pitch as due to declination, especially for longer utterances. We also see the characteristic $\mathrm{H}+\mathrm{L}^{*}$ at the head of $\varphi$ that has been described as typical for neutral declaratives. (10) therefore demonstrates an unmarked prosodic contour for BP utterances. This is hardly surprising since the utterance exhibits a canonical construction for negation and is produced without preceding context. Because the utterance is decontextualized, it is not controversial to find no deaccenting of propositional material in (10). There is no evidence for the discourse accessibility of the propositional content. After careful analysis of outof-the-blue negative utterances, we wondered what might happen when a speaker is forced to utter activated information using canonical negation as answers to yes-no questions. (11a) and (11b) display contours that were not predicted:

(11a) NEG1 answer to question Você gostou da palestra da Joana?

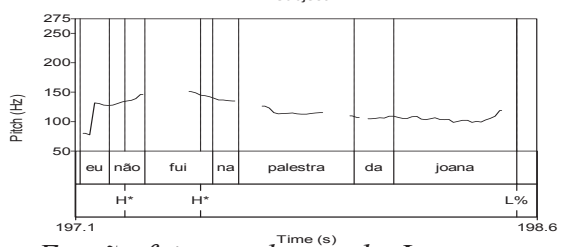

Eu não fui na palestra da Joana.

'I didn't go to Joana's talk.' (11b) NEG1 answer to question Gostou da palestra da Mariana?

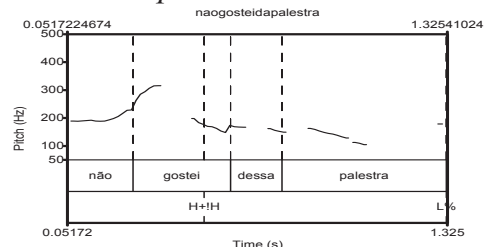

Não gostei dessa palestra.

'I didn't like that talk'. 
Meghan E. Armstrong and Scott A. Schwenter

In (11a) the speaker is asked whether she liked Joana's talk, to which she responds that she didn't go to the talk. Here there is pitch accent both on the negative particle as well as the verb, but the verb's argument is deaccented. This is information that was evoked in the question, and that in de Morães' account would be considered "redundant" and therefore require no pitch accent. Additionally, it is unexpected that the speaker didn't go to the talk, since her interlocutor asked if she liked the talk, presupposing that she went. We find pitch accent, then, on the negative particle as well as the verb. In (11b) the speaker responded to a similar question, whether or not she liked Mariana's talk. In this case she responds negatively using NEG1. There is no pitch accent on the negative particle, but rather a $\mathrm{H}+$ !H tone combination on the verb; the $\mathrm{F} 0$ contour also begins to rise within the negative particle. Speakers producing the responses for this trial commented that they would simply respond Não gostei rather than repeating the post-verbal information. This is not surprising given the Portuguese tendency to use verbal responses for yes/no questions (Sadock \& Zwicky 1985; Armstrong 2008). Therefore, in a case where a speaker would normally elide the information, when forced to produce it there is a tendency to deaccent the additional postverbal material. We can assume, then, that this information is highly accessible, and will undergo attenuation as postulated by Chafe in the form of either deaccenting or elision. Also of note in (11b) is that the verb has already been activated in the question, but there is still find pitch accent in the response. We speculate that this is also due to the tendency to respond with verbal responses in Portuguese. Because the entire VP tells the interlocutor 'yes' or 'no', the entire VP is considered new information, rather than just the negative particle.

We have successfully confirmed H1, which states that NEG1 may or may not show patterns of deaccenting in $\mathrm{BP}$. We now move on to $\mathrm{H} 2$, which was tested by eliciting NEG2 and NEG3 forms in contexts including explicitly activated information. With such information we see pragmatic overlap of the two noncanonical forms. (12a) and (12b) show typical contours for this context/form relationship across speakers:

(12a) NEG2 answer to the question Você foi na casa do Rodrigo? 'Did you go to Rodrigo's house?'

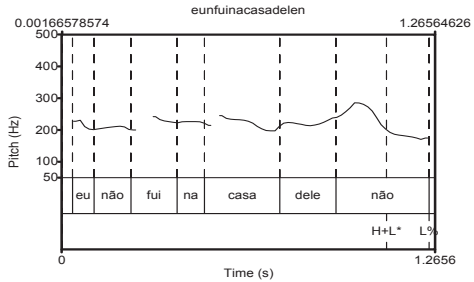

Eu não fui na casa dele não.

'I didn't go to his house.' (12b) NEG3 answer to the question Você foi na casa do Rodrigo? 'Did you go to Rodrigo's house?'

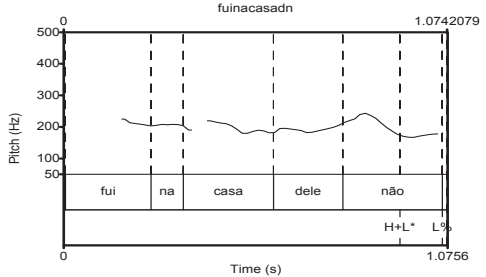

Fui na casa dele não.

'I didn't go to his house'. 


\section{Prosody, Accessibility and Sentential Negation}

The pitch tracks in $(12 \mathrm{a}, \mathrm{b})$ show that the explicitly activated proposition, i.e. that the speaker went to Rodrigo's house, does not show any pitch accent. These examples as well as others in our data confirm $\mathrm{H} 2$, that deaccenting patterns could be found for discourse-old information that was explicitly activated. It is also noteworthy that when the NEG2 version of this utterance is played to hearers without the first two lexical items eu não, making the segmental content the same as that of the NEG3 utterance, native BP speakers that listened to the two utterances found them identical. The utterances do, however, show a $\mathrm{H}+\mathrm{L}^{*}$ tone at the head of $\varphi$ typical of neutral declarative sentences. In any case, (12a, b) confirm our hypothesis that non-canonical forms evoked by explicitly activated information would show deaccenting patterns.

The last hypothesis to be tested was H3. The following examples were employed to test this hypothesis.

(13a) Pitch expansion for inferred NEG2 (Female speaker)

Context: Você está na praia e pode ver que vem um mendigo pedindo dinheiro das pessoas. Ai você fala para seu amigo:

You are at the beach and can see a beggar asking for money from people. So you say to your friend:

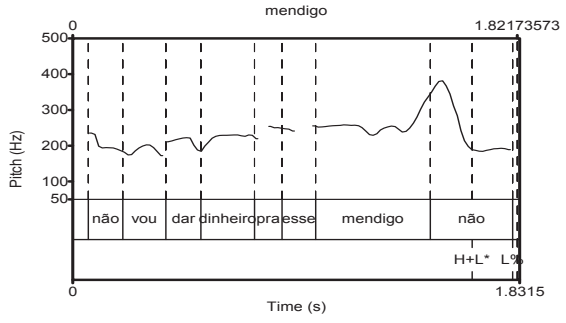

Não vou dar dinheiro pra esse mendigo não.

'I'm not going to give that beggar money.' (13b) Response to question from context: Acho que vou comprar uma passagem pra Natal. Você tá a fim? 'I think I am going to buy a ticket to Natal. Want to go?'

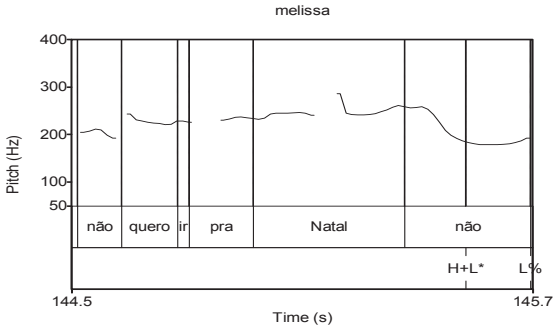

Não quero ir pra Natal não.

'I don't want to go to Natal.

In (13a) the speaker states that she would not give money to the beggar. From the presence of a beggar on the beach, it is inferrable that the beggar might want money, and therefore NEG2 is licensed. In (13b) the speaker negates explicitly activated information, i.e. that she would want to go to Natal. The difference between the two utterances is pitch height for the high target. In (13a) the speaker reaches $382.5 \mathrm{~Hz}\left(\mathrm{~F}_{0} \mathrm{Max}\right)$, whereas in (13b) the same speaker is only at $285 \mathrm{~Hz}$, within her normal pitch range. Additionally, the rise in pitch from the last syllable 
Meghan E. Armstrong and Scott A. Schwenter

of the word occurring before the second negative particle is much sharper in (13a) than in (13b). The difference between these two utterances suggests that pitch widening is used for NEG2s produced in the context of inferrable propositions.

Because all of the examples of NEG2 and NEG3 above show deaccenting of propositional content that is highly accessible, we must ask whether deaccenting is obligatory for these non-canonical forms. (14) below responds to this issue in an example in which the speaker makes the hypothesis that the propositional content was not sufficiently accessible.

Response to Context: Your mother is planning a dinner with the family. She tells you the list of invitees. She knows very well that you don't like your cousin Renata.

Mother: Vem o tio Roberto, o primo Pedro, a tia Rebeca e a tua prima Renata. 'Your Uncle Robert is coming, cousin Pedro, Aunt Rebeca, and your cousin Renata.'

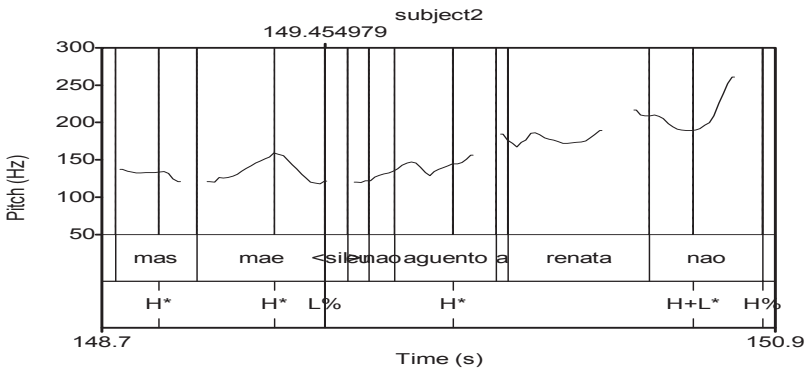

Mas mãe, eu não agüento a Renata não.

'But mom, I can't stand Renata'.

In (14) there is pitch accent on the verb agüento, rather than the typical deaccenting patterns seen in prior examples. Additionally, the speaker climbs in pitch, dropping down and back up substantially at the end of the phrase, ending with a high boundary. The speaker peaks at $263 \mathrm{~Hz}$, which is much higher than his typical range (100-150 Hz). The case is different than others addressed in this paper for various reasons. That the speaker gets along well with his cousin is relevant to the context; we can assume that he will be present at the party that his mother is talking about. Therefore, the speaker's ability to get along well with the other guests is also relevant. We might assume that the speaker is reminding his mother of his inability to deal with his cousin in a social situation, a sort of reactivation of information that the speaker believes is not active or at least not active enough in his interlocutor's mind. The speaker uses both pitch accent and pitch widening to accomplish this re-activation of information. The pitch tracks in $(13 \mathrm{a}, \mathrm{b})$ and also (14) confirm that other strategies such as pitch accent on propositional content as well as pitch widening can be used depending on context 


\section{Prosody, Accessibility and Sentential Negation}

for NEG2s. Additionally, while deaccenting is very common for NEG2s, it is not obligatory.

\section{Conclusion}

In each case of non-canonical negative syntax considered here, there is accompanying prosodic coding to mark the contrast between pieces of information of differing discourse accessibility. There is, however, no one-to-one mapping between non-canonical negative constructions and prosodic structure. Rather, speakers have a number of prosodic resources at their disposal to make explicit the relationship between (parts of) the negated proposition and the prior discourse context. These resources, as illustrated above in our data for BP, include deaccenting and pitch widening. Our hope is that future research, both on BP and other languages, will lead to more comprehensive descriptions of the ways in which non-canonical syntax and prosodic structure interact with each other.

\section{References}

Alkmim, Mônica. 2001. As negativas sentenciais no dialeto mineiro: uma abordagem variacionista. PhD diss., Universidade Federal de Minas Gerais.

Armstrong, Meghan. 2008. Pragmatic Restrictions on Affirmative Response Choice in Brazilian Portuguese. In J. Bruhn de Garavito, ed., Selected Proceedings of the $10^{\text {th }}$ Hispanic Linguistics Symposium. Somerville, MA: Cascadilla Proceedings Project.

Armstrong, Meghan; Anouschka Bergmann; and Terrin Tamati. 2008. The Prosody of Negation in Brazilian Portuguese. In Proceedings of the $4^{\text {th }}$ Conference on Speech Prosody. Campinas, Brazil. Universidade Estadual de Campinas.

Baltazani, Mary. 2006. Intonation and Pragmatic Interpretation of Negation in Greek. Journal of Pragmatics 38:1658-76.

Baumann, Steven, and Martine Grice. 2006 The Intonation of Accessibility. Journal of Pragmatics 38:1636-57.

Beckman, Mary E., and Julia Hirschberg. 1994. The ToBI annotation conventions, vers 2.0. Ms., The Ohio State University.

Chafe, Wallace, 1994. Discourse, Consciousness and Time. University of Chicago Press, Chicago.

Chafe, Wallace. 1976. Givenness, Contrastiveness, Definiteness, Subjects, Topics and Points of View. In C. N. Li, ed., Subject and topic, 25-56. New York: Academic Press.

Cruttenden, Alan. 2006. The De-Accenting of Given Information: A Cognitive Universal? In G. Bernini and M. L. Schwartz, eds., Pragmatic Organization of Discourse in the Languages of Europe, 311-55. Berlin: Mouton de Gruyter.

Crystal, David. 1975. The English Tone of Voice: Essays in Intonation, Prosody and Paralanguage. New York: St Martin's Press. 
Meghan E. Armstrong and Scott A. Schwenter

de Morães, João Antônio. 1998. Intonation in Brazilian Portuguese. In D. Hirst and A. Di Cristo, eds., Intonation Systems: a survey of twenty languages, 179194. Cambridge: Cambridge University Press.

Fernandes, Flaviane. 2007. Tonal Association of Neutral and Subject-NarrowFocus Sentences in Brazilian Portuguese. Journal of Portuguese Linguistics 5/6:91-115.

Hirst, D., and A. Di Cristo, eds, 1998. A Survey of Intonation Systems. Cambridge: Cambridge University Press.

Lambrecht, Knud. 1994. Information Structure and Sentence Form. Cambridge: Cambridge University Press.

Lucente, Luciana. 2007. Proposta de um sistema de notação entoacional para o Português Brasileiro. Partial Master's Thesis Report. UNICAMP, Campinas, Brazil.

Prince, Ellen. 1981. Toward a Taxonomy of Given-New Information. In P. Cole, ed., Radical Pragmatics, 223-255. New York: Academic Press.

Sadock, Jerrold, and Arnold Zwicky. 1985. Speech Act Distinctions in Syntax. In T. Shopen, ed., Language Typology and Syntactic Description, Volume 1, Clause structure, 155-96. Cambridge: Cambridge University Press.

Schwenter, Scott. 2005. The Pragmatics of Negation in Brazilian Portuguese. Lingua 115:1427-56.

Terken, Jacques M. B., and Julia Hirschberg. 1994. Deaccentuation of words representing 'given' information: Effects of persistence of grammatical function and surface position. Language and Speech, 37:125-145.

Tenani, Luciani E. 2002. Domínios prosódicos no português. Unpublished Ph.D. diss., Universidade Estadual de Campinas.

Vallduví, Enric. 1990. The informational component. PhD diss., University of Pennsylvania.

Ward, Gregory, and Betty J. Birner. 2006. Information Structure. In B. Aarts and A. McMahon, eds., Handbook of English Linguistics, 291-317. Oxford: Blackwell. 